\title{
ASCILITE 2020
}

\section{Assessing esport candidacy for critical thinking education}

Ger Post

The University of Melbourne Australia

\author{
James Birt \\ Bond University Australia
}

\begin{abstract}
Critical thinking in education is mainstream with ever increasing industry support for soft skills and capacity for graduates to solve problems, plan strategy, make decisions and communicate creatively. However, teaching and assessing critical thinking is resource intensive especially when scaling to large remote or online classes. Often, the solutions are bespoke, custom outcomes for a single classroom that are expensive to scale. Commercial computer games and esports may offer a solution. In this paper we aim to define critical thinking in education and how this relates to skills in esports, including decision making, problem solving, making a game plan, developing strategy and communication. To achieve this, we propose a conceptual framework to assess effectiveness of esports in teaching critical thinking using an adapted digital game-based learning framework and the learning goals of critical thinking. We support the framework with an esport case example of Rocket League with a lesson plan.
\end{abstract}

Keywords: Critical Thinking, Esports, Education, Rocket League, Games Based Learning Introduction

Transferable skills such as problem solving, communication and teamwork are on the rise from enterprise Australia and increasingly valued in graduates (FYA, 2018). These soft skills are often intertwined with critical thinking which has been identified by The World Economic Forum (Leopold, Ratcheva, \& Zahidi, 2018) as a skill for now and the future. There are many definitions of critical thinking in the literature but this paper uses the American Philosophical Association expert Delphi Panel definition which describes critical thinking as, "purposeful, self-regulatory judgment that results in interpretation, analysis, evaluation, and inference, as well as explanation of the evidential, conceptual, methodological, criteriological, or contextual considerations on which that judgment is based" (Facione, 1990, p. 2).

Critical thinking has been argued as essential in many domains of higher education, including teaching students to make better clinical, legal, business and policy decisions (Gambrill \& Gibbs, 2017). van Peppen et al. (2018) considers critical thinking as "an important competence for students and graduates of higher education" (p. 1) but cautions on the teaching methods to effectively support critical skills acquisition and transfer. Specifically, the problem of unbiased reasoning which relates to providing students with explicit instruction and giving them the opportunity to practice what has been learned may improve performance on the learned task but not the learning transfer (Halpern, 1998). Therefore, although Australian Universities claim to teach students critical thinking skills for life-long learning (Oliver \& Jorre de St Jorre, 2018), there is little evidence that a university education enhances critical thinking.

In this paper we propose a conceptual framework to assess effectiveness of esports for teaching critical thinking using an adapted digital game-based learning framework and the learning goals of critical thinking. We support the framework with an esport case example of Rocket League with a lesson plan, to answer the research question, "How can commercial esports be adapted for critical thinking education?".

\section{Background}

Studies showing that students gain critical thinking skills at university do not distinguish the effects of higher education from ordinary maturation effects (Huber \& Kuncel, 2016), which is a persistent problem in the critical thinking body of research. This makes it very difficult to conclude whether the observed effects are the result of education or just maturity. One extensive study by Arum and Roksa (2011) suggests that students show little if any growth in their ability to perform tasks requiring critical thinking and complex reasoning, and it has been argued that university graduates are unprepared to think critically once in the workforce (Flores, Matkin, Burbach, Quinn, \& Harding, 2012). One reason for these results may be the lack of methods for improving critical thinking that are both practical for large-scale implementation, and demonstrably effective. 
Well-designed software can assist by enhancing the intrinsic motivation that tends to promote learning more than external motivation with methods including cooperative learning games (Lee et al., 2016) and online social interactions (Hussin, Harun, \& Shukor, 2019). However, the cost is often high, difficult to scale, and impossible to maintain long term (Tsekleves, Cosmas, \& Aggoun, 2016). Moreover, in education design it is often a dilemma when to start teaching critical thinking (Vink, de Greef, Post, \& Wenting, 2017), with quality practice (Gelder, 2001) and knowledge (Smith, 2014) central to critical thinking. One way for learners to practice critical thinking despite having insufficient knowledge, is to practice transferrable skills in a domain they likely have (or can easily acquire) knowledge in. It is in this respect that we see esports' biggest potential.

Esports is a term that describes a rapidly evolving area of media, competition, and industry disruption formed around video games played competitively for spectators, typically by professional gamers belonging to teams coordinated by different leagues, ladders and tournaments (Birt, 2018). Since COVID-19 hitting in early 2020 esports has seen a massive spike in both people playing and spectating, with the latest Newzoo (2020) esports data report estimating a total worldwide audience for esports in 2020 at 495 million people with estimates of 646 million by 2023, representing more than 10 percent year on year growth despite the pandemic. At first esports may not be an obvious candidate to train critical thinking, with definitions of esports often emphasising what physical aspects of sports are replicated by electronic systems (Hamari \& Sjöblom, 2017), degrees of spectatorship (Summerley, 2019) and ethical considerations (Murray, Birt, \& Blakemore, 2020). But, recent studies have started focusing on sustainable aspects of esports (Murray et al., 2020), including cognitive functions such as working memory (Pedraza-Ramirez, Musculus, Raab, \& Laborde, 2020) and cognitive flexibility which are typically involved in decision making (Reitman, Anderson-Coto, Wu, Lee, \& Steinkuehler, 2019).

Reflective decision making skills has largely been neglected in higher education just as they have been in sports (Lyle \& Vergeer, 2013), despite a well-established link between sports coaches' expertise and skills in critical thinking and decision making (Nash \& Collins, 2006). Strategic decision making, often attributed to coaches in sports, may have the most potential in training critical thinking in esports. Esports players often develop strategic game plans based on scenarios, probability calculations and previous experience. They do this in an environment that not only captures a lot of these deliberations but also the results of these decisions, which provides valuable input for critical reflections on these decisions. When a game plan leads to a win (for example), or measurable improvement, a question to contemplate is whether this means that the decision to follow this strategy was right.

Paul and Elder (2019) Elements of Thought are an adaptation of the scientific method of hypothesis formulation and testing and used to train decision making and critical thinking in professional sport coaches in the Australian Football league (AFL) and the Dutch Olympic Team. Focusing on Clarity, Accuracy, Precision, Relevance, Depth, Breadth, Logic, Significance, and Fairness. Interestingly, there is quite some evidence that esports players naturally engage with these sorts of critical reflections to win (or improve in) esports matches. A survey revealed that players think video games not only train their social (i.e., negotiation) and motor spatial skills, but also their cognitive skills including problem solving and strategy development (Turkay \& Adinolf, 2012). These findings have been supported by researchers in esports who describe how players and fans often approach games such as League of Legends in a data-driven and statistical way (Anderson et al., 2018).

Although it has been argued that one learns to think critically by following an intellectual tradition or discipline (Jones, 2015), we believe that components of problem-solving and critical thinking are intrinsically general in nature (Gelder, 2001, 2005) and can be practiced in teams. The transfer of critical skills does not happen automatically. Educators must teach for transfer (Billing, 2007; Halpern, 1998) and students must practice the art of transferring the skills from one situation to another (Gelder, 2005). In this light, practicing critical thinking in esports should be followed up by reflection on these skills and how they may be relevant in other contexts within the discipline-based curriculum and beyond.

\section{Theoretical framework}

To assess esport effectiveness, we propose a framework based on a conceptual model developed by All, Nuñez Castellar, and Van Looy (2015) assessing effectiveness of digital game-based learning and critical thinking learning goals based on (Facione, 1990, 2020) definition. All et al. (2015) operationalises three categories of desired outcomes, these are learning, motivational and efficiency outcomes. These outcomes can be further subdivided and organised. Learning outcomes relevant to the effectiveness of esports are mapped against Facione (2020) to include: increased interest in critical thinking that help to make better decisions, improvement in objective performance, transfer of critical thinking and decision making in the game to real-world situations. Motivational outcomes entail that learning within the esport is both enjoyable and motivating. Efficiency outcomes are important factors for scale and concern time management and cost-effectiveness (see Table 1). 
Table 1: Framework to assess esport effectiveness adapted from All et al. (2015) and Facione (2020)

\begin{tabular}{|l|l|l|}
\hline $\begin{array}{l}\text { Learning outcomes } \\
\text { Situational interest: Esport } \\
\text { stimulates interest in critical thinking } \\
\text { processes that help to make better } \\
\text { decisions in the game. }\end{array}$ & $\begin{array}{l}\text { Enjoyment: Esport } \\
\text { succeeds in creating an } \\
\text { enjoyable game } \\
\text { experience. }\end{array}$ & $\begin{array}{l}\text { Time management: Esports succeeds } \\
\text { in reducing the timeframe required to } \\
\text { teach a certain content matter. This is a } \\
\text { judgment of relative worth compared to } \\
\text { other instructional methods. }\end{array}$ \\
\hline $\begin{array}{l}\text { Performance: Esport succeeds in } \\
\text { achieving the learning goal to train } \\
\text { purposeful, self-regulatory decision } \\
\text { making that result from interpretation } \\
\text { analysis, evaluation, and inference, as } \\
\text { well as explanation of the contextual } \\
\text { considerations on which that decision } \\
\text { is based. }\end{array}$ & $\begin{array}{l}\text { Motivation towards } \\
\text { sport: Learning with } \\
\text { the esport is motivating. } \\
\text { This is a judgment of } \\
\text { relative worth, compared } \\
\text { to other instructional } \\
\text { methods. }\end{array}$ & $\begin{array}{l}\text { Cost-effectiveness: The esport } \\
\text { succeeds in reducing the cost of the } \\
\text { intervention regarding: (i) the number } \\
\text { of learners that can be reached, and (ii) } \\
\text { the time required to teach the target } \\
\text { group certain content. This is a } \\
\text { judgment of relative worth, compared } \\
\text { to other instructional methods. }\end{array}$ \\
\hline $\begin{array}{l}\text { Transfer: The esport stimulates application of learned decision making in the game to real world situations in } \\
\text { the classroom discipline. }\end{array}$
\end{tabular}

\section{Assessing esport effectiveness to train critical thinking}

To answer the research question "How can commercial esports be adapted for critical thinking education?", we have provided a case study example using the popular esport Rocket League (https://www.rocketleague.com/). Rocket League has been selected because its (i) popular, (ii) free online gameplay with low cost to entry, (iii) provides digital tools for game capture and reflection and (iv) non-violent team-based competition. Table 2 illustrates the mapping of Rocket League to the theoretical framework in Table 1.

Table 2: Assessing Rocket Leagues effectiveness in training critical thinking for transfer

\begin{tabular}{|c|c|c|}
\hline Learning outcomes & Motivational outcomes & Efficiency outcomes \\
\hline $\begin{array}{l}\text { Situational interest: A large } \\
\text { component for Rocket League is } \\
\text { the selection of a game plan. A } \\
\text { critical decision, for example, is } \\
\text { whether the team is going to } \\
\text { follow an attacking or a } \\
\text { defending strategy. }\end{array}$ & $\begin{array}{l}\text { Enjoyment: Rocket League is } \\
\text { one of the most popular } \\
\text { esports, because it combines a } \\
\text { ball game with a car game. } \\
\text { Games are broadcasted on } \\
\text { Twitch/YouTube and have } \\
\text { large audience reach. }\end{array}$ & $\begin{array}{l}\text { Time management: Rocket Lea } \\
\text { entry threshold. Participants lea } \\
\text { relatively quickly, compared to } \\
\text { games such as League of Leger } \\
\text { provides a reasonable amount o } \\
\text { be used to critically reflect on d } \\
\text { making. }\end{array}$ \\
\hline $\begin{array}{l}\text { Perfo } \\
\text { game } \\
\text { up, a } \\
\text { analy } \\
\text { game } \\
\text { plans } \\
\text { and h } \\
\text { outco }\end{array}$ & $\begin{array}{l}\text { Moti } \\
\text { Rock } \\
\text { milli } \\
\text { worl } \\
\text { this } \\
\text { to wi } \\
\text { facto } \\
\text { game }\end{array}$ & $\begin{array}{l}\text { cceeds } \\
\text { with } \\
\text { te } \\
\text { the } \\
\text { is } \\
\text { ent and } \\
\text { ved }\end{array}$ \\
\hline \multicolumn{3}{|c|}{$\begin{array}{l}\text { Transfer: Rocket league stimulates application of learned decision making in the game by allowing the learners } \\
\text { to capture their communication within the team, explore iterative game plans, adjust, and reflect on their games } \\
\text { in a time effective manner. These are all skills required for critical thinking applied beyond the esport into } \\
\text { discipline domains and further learning. }\end{array}$} \\
\hline
\end{tabular}

To illustrate application of the approach we have provided an example lesson plan, which is adapted from the lead authors (and Vincent Tijms) approach for training sport coaches from the AFL and Dutch Olympic Teams.

Prior to class 1: students are placed into teams of three to play Rocket League; the team leader is required to play the game and activate a spectator camera integrated in the game to capture team performance for reflection.

In class 1: students reflect on their game performance using the captured spectator view of the game. Students are asked to focus on one thing they want to improve in the next game by following an adapted set of questions from Paul and Elder (2019) Elements of Thought as reflection presented in Table 3 and in 'In class 2'. 
Table 3: Reflective questions adapted from Paul and Elder (2019)

\begin{tabular}{|l|l|l|}
\hline $\begin{array}{l}\text { What: Explain your problem or point } \\
\text { for improvement as specific as } \\
\text { possible }\end{array}$ & $\begin{array}{l}\text { How: Explain how your plan will lead } \\
\text { to an improvement by going into as } \\
\text { much details as possible }\end{array}$ & $\begin{array}{l}\text { Really: Actively look for } \\
\text { counterarguments and evidence }\end{array}$ \\
\hline $\begin{array}{l}\text { What would you like to improve, or is } \\
\text { there a problem you would like to } \\
\text { solve? }\end{array}$ & $\begin{array}{l}\text { Provide a mechanistic explanation to } \\
\text { make your assumptions explicit. } \\
\text { i.e., how exactly does your plan lead } \\
\text { to the intended result? More } \\
\text { assumptions can be detected by } \\
\text { asking 'how?' and 'why? }\end{array}$ & $\begin{array}{l}\text { Can you think of counterexamples, or } \\
\text { reasons why your plan may not work } \\
\text { or may be counterproductive? }\end{array}$ \\
\hline $\begin{array}{l}\text { How did you determine this problem } \\
\text { or point for improvement? }\end{array}$ & $\begin{array}{l}\text { Map out the evidence for your } \\
\text { assumptions. i.e., how do you know } \\
\text { that your plan will lead to the } \\
\text { intended result? What evidence } \\
\text { supports your assumptions? }\end{array}$ & $\begin{array}{l}\text { Can you think of alternative plans? } \\
\text { How are those plans better or worse } \\
\text { than the plan you propose? }\end{array}$ \\
\hline $\begin{array}{l}\text { How can you see progress, and can } \\
\text { you measure it? }\end{array}$ & & \\
\hline
\end{tabular}

Prior to class 2: students play another game of Rocket League, with the team leader recording the performance.

In class 2: students reflect on their game performance using the captured spectator view of the game. They are asked to evaluate their plan. To what extend did they follow their plan and to what extend did that lead to the intended result? What does the actual result say about their decision? Are they considering all information? Is there another way to interpret the information? After this lesson, the lead educator and the students will apply this process to discipline-based problems aiding transfer.

Conclusions and future work

We argued that esports provide an engaging, motivating environment in which students can practice critical thinking skills to evaluate decision making. This paper has proposed a framework for assessing esport candidacy for training critical thinking for transfer. A candidate commercial esport, Rocket League, has been provided including the proposed integration to the classroom setting through an educational lesson plan. The future of this research is to apply the plan in an educational learning environment following a qualitative research methodology. The aim is to better understand the applied application of the method and refine both the framework and lesson approach.

\section{References}

All, A., Nuñez Castellar, E. P., \& Van Looy, J. (2015). Towards a conceptual framework for assessing the effectiveness of digital game-based learning. Computers \& Education, 88, 29-37. doi:10.1016/j.compedu.2015.04.012.

Anderson, C. G., Tsaasan, A., Reitman, J., Lee, J. S., Wu, M., Steel, H., . . Steinkuehler, C. (2018). Understanding esports as a STEM career ready curriculum in the wild. Paper presented at the 10th International Conference on Virtual Worlds and Games for Serious Applications. https://ieeexplore.ieee.org/document/8493445

Arum, R., \& Roksa, J. (2011). Limited Learning on College Campuses. Society, 48(3), 203. doi:10.1007/s12115011-9417-8.

Billing, D. (2007). Teaching for transfer of core/key skills in higher education: Cognitive skills. Higher Education, 53(4), 483-516. doi:10.1007/s10734-005-5628-5.

Birt, J. R. (2018). eSports are shifting the focus of Australia's sporting passion. The Conversation. https://theconversation.com/esports-are-shifting-the-focus-of-australias-sporting-passion-93076

Facione, P. (1990). Critical thinking: A statement of expert consensus for purposes of educational assessment and instruction (The Delphi Report). https://eric.ed.gov/?id=ED315423

Facione, P. (2020). Critical thinking: What it is and why it counts. 1-33.

https://www.insightassessment.com/article/critical-thinking-what-it-is-and-why-it-counts

Flores, K. L., Matkin, G. S., Burbach, M. E., Quinn, C. E., \& Harding, H. (2012). Deficient critical thinking skills among college graduates: Implications for leadership. Educational Philosophy and Theory, 44(2), 212-230. doi:10.1111/j.1469-5812.2010.00672.x.

FYA. (2018). The New Work Reality. https://www.fya.org.au/report/the-new-work-reality/

Gambrill, E., \& Gibbs, L. (2017). Critical thinking for helping professionals: A skills-based workbook: Oxford University Press. 
Gelder, T. v. (2001). How to improve critical thinking using educational technology. Paper presented at the 18th Australian Society for Computers in Learning in Tertiary Education Conference. https://www.ascilite.org/conferences/melbourne01/pdf/papers/vangeldert.pdf

Gelder, T. v. (2005). Teaching Critical Thinking: Some Lessons From Cognitive Science. College Teaching, 53(1), 41-48. doi:10.3200/CTCH.53.1.41-48.

Halpern, D. F. (1998). Teaching critical thinking for transfer across domains. Dispositions, skills, structure training, and metacognitive monitoring. Am Psychol, 53(4), 449-455. doi:10.1037//0003-066x.53.4.449.

Hamari, J., \& Sjöblom, M. (2017). What is eSports and why do people watch it? Internet research, 27(2), 211232. doi:10.1108/IntR-04-2016-0085.

Huber, C. R., \& Kuncel, N. R. (2016). Does College Teach Critical Thinking? A Meta-Analysis. Review of Educational Research, 86(2), 431-468. doi:10.3102/0034654315605917.

Hussin, W. N. T. W., Harun, J., \& Shukor, N. A. (2019). Online Interaction in Social Learning Environment towards Critical Thinking Skill: A Framework. Journal of Technology and Science Education, 9(1), 4-12. doi:10.3926/jotse.544.

Jones, A. (2015). A disciplined approach to critical thinking. In The Palgrave handbook of critical thinking in higher education (pp. 169-182): Springer.

Lee, H., Parsons, D., Kwon, G., Kim, J., Petrova, K., Jeong, E., \& Ryu, H. (2016). Cooperation begins: Encouraging critical thinking skills through cooperative reciprocity using a mobile learning game. Computers \& Education, 97, 97-115. doi:10.1016/j.compedu.2016.03.006.

Leopold, T. A., Ratcheva, V., \& Zahidi, S. (2018). The Future of Jobs Report. Retrieved from http://reports.weforum.org/future-of-jobs-2018/

Lyle, J., \& Vergeer, I. (2013). Recommendations on the methods used to investigate coaches' decision making. In P. Potrac, W. Gilbert, \& J. Denison (Eds.), Routledge handbook of sports coaching (pp. 121-132). London, United Kingdom: Routledge.

Murray, S., Birt, J., \& Blakemore, S. (2020). eSports diplomacy: towards a sustainable 'gold rush'. Sport in Society, 1-19. doi:10.1080/17430437.2020.1826437.

Nash, C., \& Collins, D. (2006). Tacit Knowledge in Expert Coaching: Science or Art? Quest, 58(4), $465-477$. doi:10.1080/00336297.2006.10491894.

Newzoo. (2020). Global Esports Market Report. Retrieved from https://newzoo.com/insights/trendreports/newzoo-global-esports-market-report-2020-light-version/

Oliver, B., \& Jorre de St Jorre, T. (2018). Graduate attributes for 2020 and beyond: recommendations for Australian higher education providers. Higher Education Research \& Development, 37(4), 821-836. doi:10.1080/07294360.2018.1446415.

Paul, R., \& Elder, L. (2019). The miniature guide to critical thinking concepts and tools: Rowman \& Littlefield.

Pedraza-Ramirez, I., Musculus, L., Raab, M., \& Laborde, S. (2020). Setting the scientific stage for esports psychology: a systematic review. International Review of Sport and Exercise Psychology, 1-34. doi:10.1080/1750984X.2020.1723122.

Reitman, J. G., Anderson-Coto, M. J., Wu, M., Lee, J. S., \& Steinkuehler, C. (2019). Esports Research: A Literature Review. Games and Culture, 15(1), 32-50. doi:10.1177/1555412019840892.

Smith, F. (2014). To think: In language, learning and education: Routledge.

Summerley, R. (2019). The Development of Sports: A Comparative Analysis of the Early Institutionalization of Traditional Sports and E-Sports. Games and Culture, 15(1), 51-72. doi:10.1177/1555412019838094.

Tsekleves, E., Cosmas, J., \& Aggoun, A. (2016). Benefits, barriers and guideline recommendations for the implementation of serious games in education for stakeholders and policymakers. British Journal of Educational Technology, 47(1), 164-183. doi:10.1111/bjet.12223.

Turkay, S., \& Adinolf, S. (2012). What do Players (Think They) Learn in Games? Procedia - Social and Behavioral Sciences, 46, 3345-3349. doi:10.1016/j.sbspro.2012.06.064.

van Peppen, L. M., Verkoeijen, P. P. J. L., Heijltjes, A. E. G., Janssen, E. M., Koopmans, D., \& van Gog, T. (2018). Effects of Self-Explaining on Learning and Transfer of Critical Thinking Skills. Frontiers in Education, 3(100). doi:10.3389/feduc.2018.00100.

Vink, C., de Greef, L., Post, G., \& Wenting, L. (2017). Designing interdisciplinary education: A practical handbook for university teachers: Amsterdam University Press.

Post, G. \& Birt, J. authors (2020). Assessing esport candidacy for critical thinking education. In S. Gregory, S. Warburton, \& M. Parkes (Eds.), ASCILITE's First Virtual Conference. Proceedings ASCILITE 2020 in Armidale (pp. 295-300). https://doi.org/10.14742/ascilite2020.0112

Note: All published papers are refereed, having undergone a double-blind peer-review process. 
The author(s) assign a Creative Commons by attribution licence enabling others to distribute, remix, tweak, and build upon their work, even commercially, as long as credit is given to the author(s) for the original creation.

(C) Post, G. \& Birt, J. 2020 